\title{
Is it wrong for us to want good things? The origins of Gompers Charter Middle School
}

\author{
Hugh B. Mehan • Gordon C. Chang
}

Published online: 8 July 2010

(C) The Author(s) 2010. This article is published with open access at Springerlink.com

\begin{abstract}
This paper documents the initial process by which a San Diego middle school, located in a low-income and predominantly Hispanic neighborhood and repeatedly failing to meet No Child Left Behind provisions, restructured into an academically rigorous, detracked charter school. The discussion of the political experience and working relationships between the charter organizers, the school district, and its superintendent illustrate the often contentious process of community mobilization and deliberation. The involvement of faculty from the University of California San Diego and community groups as contributing partners enhances our understanding of the creation of educational reforms or the transformation of passion into practice.
\end{abstract}

Keywords Charter schools - School reform - Restructuring - Detracking · School-university partnerships · District politics - College-going school culture

Good things don't happen to Gompers often, and when they do, it's taken away.... We had a lot of different principals who we did not care for. But this one made great changes. We Gompers' students see these changes and, for once, we want this, because we see that it is good for us. Is it wrong for us to want good things? [italics added]

(Saadati 2005)

These words were spoken passionately by Maryam Saadati, an eighth-grade student from Gompers Middle School, when she addressed the San Diego Unified

H. B. Mehan $(\bowtie) \cdot$ G. C. Chang

Center for Research in Educational Equity, Assessment, and Teaching Excellence (CREATE),

University of California, San Diego, 9500 Gilman Drive MC 0036, La Jolla, CA 92093-0036, USA

e-mail: bmehan@ucsd.edu

G. C. Chang

Western Illinois University, 1 University Circle, Macomb, IL 61455, USA 
School Board on March 1, 2005. She captured eloquently the sentiments of her community members who expressed frustration at having their school and community neglected by local, state, and federal government.

Saadati's assessment of the conditions at Gompers before it converted to charter status is supported by official evidence. Allison Kenda, Gompers' chief of staff, reported to the California Charter Schools Association an indication of the troubled conditions facing parents and students: Gompers Middle School had 18 teacher vacancies out of a teaching staff of 50 when the school opened in 2004 with 6 vacancies in math and science remaining in January of that school year and teacher attrition rates above $70 \%$. This meant students were faced with a revolving door of substitute teachers-hardly a condition conducive to accelerating learning and reaching the annual progress goals of the No Child Left Behind Act of 2001 (NCLB). Kenda reported that teacher absences were matched by student absences with the average daily attendance rate hovering near $90 \%$. In addition to an excessive number of teacher vacancies, the physical plant was left to deteriorate. Teachers assigned to the school expressed open disdain for their students. Fights, severe enough to require police intervention and over 1,000 suspensions per year, occurred regularly (Kenda 2008). Vincent Riveroll, school principal, relayed a particularly poignant first-hand experience personalizing these chilling statistics. On one of his first days as principal of the "old" Gompers, a student stopped him and asked, "Why are you wearing a suit, man? It's just gonna' get ripped up the first time you try to break up a fight" (V. Rivroll, personal communication, February 1, 2006).

Saadati offered her comments during the debate before the San Diego Unified School Board about granting charter school status to the parents and educators associated with Gompers Middle School. The school's principal, Vincent Riveroll, had been unceremoniously removed by the school board previously; Saadati was imploring the board to return her principal and approve the petition for a charter school at Gompers. The petition was approved, but only after a rancorous debate that afternoon and many afternoons before that.

\section{Documenting the creation of an educational reform}

Seymour Sarason, arguably the dean of the study of educational reform, has lamented that scholars have not studied the creation of educational reforms (Sarason 1972, 1997). There are ample studies of educational implementation, he says, but very few studies of the formation of the original prototype. Sarason's observations about federal mandates and district-wide reforms ring true for charter schools as well. While much has been written about the rationale for charter schools, the characteristics of their student populations, debates over their capability to increase students' learning, and their success in stimulating competition in conventional public schools, little has been written about how actual charter schools come into being. Only a few studies (e.g., Deal and Hentschke 2004; Meier 1995; Rofes 2000; Schorr 2002), in varying levels of details, have described the actual experiences of setting up charter schoolsthat is moving from the passion and commitment of a dedicated and diverse group of founders to the everyday routines of educational practice. 
The educators and researchers associated with Gompers Charter Middle School have a unique opportunity to describe the "creation of a setting" (Sarason 1972, 1997), that is, to document the often contentious process of forming a particular charter school so that an accurate record is available for people interested in attempts to improve the academic performance of socioeconomically disadvantaged students. This paper seeks, first, to fill the gap Sarason identifies by telling the story of the formation of Gompers Charter Middle School (GCMS) in San Diego in 20042005. Secondly, it aims to improve upon Sarason's recommendation by making the technical and political dimensions of organizational change, especially attempts at school reform, more explicit.

We start from the point the district notified the leaders of Gompers Middle School in September 2004 that the school needed to reconstitute under the provisions of federal law, NCLB. We continue to unfold the story through the time when parents and educators decided to convert Gompers Middle School into a charter school and their petition was approved by the San Diego Unified School District Board in March 2005. We conclude the story with comments on the development of the school since its opening in September 2005.

To place the story in its historical context, we first describe the research methods used in the study, characterize charter schools, and then describe the school GCMS replaced-Gompers Secondary School which was then a 7-12 school.

\section{Research methods}

This is a participant-observation study. Consistent with this time-honored research technique prevalent in sociology and anthropology, we simultaneously participated in events, observed, and reported on them. The observations presented here, therefore, are written based on our experiences. We participated in a wide range of activities associated with the formation of GCMS from September 2004, through the approval of the charter by the San Diego Unified School District in March 2005, to the opening of the school in September 2005. These activities included approximately 20 weekly (and sometimes twice-weekly) working group meetings composed of school personnel, parents, and community members; 4 school board meetings; 7 one-on-one meetings with charter association members, school board members, district staff, and the district superintendent; and 13 small group meetings with faculty members from the University of California, San Diego (UCSD) and students. We tried to keep notes during these meetings; but frankly because of the emotional intensity in many of these encounters, our participant role often overshadowed our observer role. When we became engrossed in the heat of the moment, we took notes as soon after encounters as possible-usually within 24 hours. When contemporaneous information is available, we augment our recollection of events with direct quotes from other participants-some gathered from transcripts of videotape of public meetings, others from news reports of events.

The activity of conducting research is never value neutral. Researchers, especially those engaged in observational studies, shape research by their selection of topics to investigate, materials to analyze, and instances of data to interpret 
(Cicourel 1964). Researchers do not simply observe and report 'brute facts;' by their very engagement with people and artifacts in research settings, they shape materials into interpretations. The inevitable reflexive relation between researchers and objects of study was made even more complicated in this study because of the special relationship the authors have to the school.

Mehan's access to Gompers was facilitated because he helped shape the school, is a member of the board of directors, and directs the research center that is responsible for developing academically rigorous schools for students of color from low-income neighborhoods and documenting the change process associated with that development. This center and its mandate to accelerate the learning of underserved children emerged in the late 1990's when, first, the Regents of the University of California and then the voters of California eliminated affirmative action. UCSD responded to the challenge of developing a diverse student body on its campuses in the absence of affirmative action and assisting underserved urban schools by establishing the Center for Research in Educational Equity, Access, and Teaching Excellence (CREATE) and the Preuss School on the UCSD campus. CREATE uses the Preuss School as a model for other public schools in the San Diego region and across the country by seeking to better educate underrepresented minority students.

Mehan's position with CREATE enabled him to participate in, observe, and report on planning meetings, university meetings, school board meetings, and participate in the preparation of GCMS's charter documents and presentations to the San Diego Unified School District (SDUSD) school board. Chang's involvement was less direct; he joined the research effort in 2008, participated in and observed several events and meetings at the school, and interviewed educators for a paper in progress on the recruitment and retention of teachers and a second paper on the expansion of Gompers to a grade 6-12 school.

These special relations cut two ways. On the one hand, they facilitated entrée because some degree of trust had been established; on the other hand, reviewers can conclude that our objectivity has been clouded by these close relations. Rather than ignore these close relations, we acknowledge and make them visible in the analysis that follows. Therefore, our findings cannot be viewed as some disinterested representation of the 'truth,' but outline our most thorough and informed representations of our interpretations gathered during hours of participation and observation at the school.

\section{Studies of charter schools}

Charter schools are elementary or secondary schools that receive public money but have been freed from some rules, regulations, and statutes in exchange for some type of accountability for producing certain results in student achievement. According to a National Charter School Research Project (NCSRP) survey, 3,403 charter schools served over 900,000 students during the 2004-2005 school year. As of January 2006, 40 states and the District of Columbia passed charter school legislation (Ziebarth et al. 2005). By 2008, there were 35 charter schools in the San 
Diego district enrolling 13,000 students, almost $10 \%$ of the district's students. Thirty of the 35 charters were "South of 8 "-the symbolic and actual boundary separating the well-to-do neighborhoods and the less-well-off neighborhoods in San Diego ("A Test for Schools" 2008).

Many reasons have been offered for the emergence of charter schools. Some critics of public education have claimed that public schools are failing so badly that radical restructuring in the form of voucher plans is necessary (Chubb and Moe 1990). Charter schools are seen as a less radical and more viable alternative than public funding of private schools and voucher plans (Hart and Burr 1996). The stimulating effect of competition is also invoked as a rationale for charter schools. If parents vote with their feet by enrolling in charter schools, then educators in regular public schools will be motivated to be more effective in order not to lose students to charter schools. Failing public schools will either improve or close. Charter schools are also seen as an antidote to overly bureaucratic public school systems that stifle creativity. Built on an "anti-bureaucracy" rationale, charter school proponents claim that school district offices, state capitols, and/or the federal government are so distant from local schools that they impede needs expressed at the local level. Liberating educators from remote bureaucratic regulations and union contracts, then, can foster experimentation of novel approaches that may produce improved student achievement.

Assessments of the rationales for charter schools to date reveal a mixed record. ${ }^{1}$ There is not much evidence that public schools and charter schools learn from each other (Carnoy et al. 2005; Wells et al. 1998; Zimmer et al. 2009). With full-frontal teaching, standard-length periods for instruction, and textbook-based learning, many charter schools look like conventional schools. Carnoy et al. (2005) find no evidence to support the claim that charter schools foster competition among regular public schools. A more recent study (Zimmer et al. 2009) also failed to discern any competitive impact between charter schools and nearby public schools. Critics of charter schools contend that the benefit of increased choice to parents and flexibility to administrators comes at the cost of reduced job security to school personnel. They worry that the high turnover of staff associated with charter schools undermines school performance more than it enhances it.

Assessments of the performance of charter schools compared to regular public schools also reveal mixed results. Drawing from interview data from 225 charter schools in 10 states, the US Department of Education concluded in 1997 that charters tend to be new and small with fewer than 200 students. They are more often in urban than rural areas. While they tend to be more racially diverse, they tend to enroll fewer special needs and limited English proficient students than typical public schools in their respective states (US Department of Education 1997). Some scholars worry that charter schools actually lead to more, not less, segregation by social class and race (Carnoy et al. 2005; Renzulli and Roscigno 2007; Wells et al. 1998). Based on a study of eight US states, Zimmer et al. (2009) concluded that charter schools in the aggregate do not seem to cause dramatic racial or achievement segregation within

\footnotetext{
${ }^{1}$ For a comprehensive review of charter schools published in this journal, see Hubbard and Kulkarni (2009).
} 
neighborhoods. However, in some sites and in some states, charter institutions do significantly enroll students with different academic and/or racial profiles than nearby traditional public schools. However, because such patterns are not uniform, the aggregate differences are minimal and not necessarily meaningful. For example, charter schools enroll higher achieving students in some sites and lower achieving ones in others.

A meta-analysis of 26 studies of students' performance reports the findings of 12 studies indicating that students' gains in charter schools were larger than other public schools; 4 found charter schools' gains higher in elementary schools, high schools, or schools serving at-risk students; 6 found comparable gains in charter and traditional public schools; and 4 found that charter schools' overall gains lagged behind (Hassel and Terrell 2006). The meta-analysis also reports that 5 of 7 studies found that charter schools improve as they achieve organizational stability. Carnoy et al. (2005) present opposite conclusions. Based on 19 studies conducted in 11 states and the District of Columbia, these authors conclude there is no evidence on average that charter schools outperform regular public schools. Zimmer et al. (2009) also found few differences in test scores between non-primary charter schools and public schools nearby; but, charter high schools seem to have a positive association with high school graduation and college enrollment.

In sum, the available evidence on the comparison between charter schools and conventional public schools is mixed. One can find as many studies that suggest charter schools outperform conventional schools as one can find evidence in the opposite direction. So, too, the claim that charter schools foster competition and improvement in conventional public schools finds as much support as does the opposite claim. However, the vast majority of these studies are "single point in time" assessments that compare entire student cohorts from one year to the next without considering patterns of student transience and transfer. Because this year's sixth-graders may not be the same children as last year's fifth-graders in the schools being compared, we do not know if students within schools are improving academically. School-wide averages, rather than comparing students, also reveal nothing about whether all students achieve at about the same level or whether some students are achieving a great deal more than others.

An accurate assessment of school effectiveness requires information on student performance from at least two points in time (Betts and Hill 2006; Center for Educational Reform 2004). The most foolproof method to compare the performance of students in charter schools and regular public schools is an experiment (or "quasi-experiment") in which students would be randomly offered admission to charter schools; those not accepted into the school by lottery would return to their public schools, thus enabling a comparison among students over time. Betts and Hill (2006) report that only two randomized quasi-experiments have been conducted to date. One of these, conducted at the Preuss School at UCSD (McClure et al. 2005), showed that Preuss graduates enrolled in 4-year colleges at a substantially greater rate than students in the randomly selected comparison group.

A different collection of studies covers the social organization of charter schools rather than comparing charter schools and conventional public schools. Topics include issues that pertain to sustaining existing charter schools such as the role of 
"venture philanthropy" as a force in charter school advocacy (Scott 2009), problems with curricular conformity (Lubienski 2004), legal requirements (Vergari 2002), management organizations (Bulkley and Wohlstetter 2004), teacher qualifications and retention (Miron and Nelson 2002), revenue streams (Miron and Nelson 2002), selective admissions (Wells et al. 2000), and a mixture of these features (Bulkley and Wohlstetter 2004; Merseth et al. 2009; Wells 2002).

These studies tend to treat charter schools in the aggregate and provide general descriptions of their evolution as a social movement (e.g., DeBray-Pelot et al. 2007; Vergari 2002). Many of the schools described serve primarily middle-class populations (see Deal and Hentschke 2004; Fuller 2000; Nehring 2002). This paper departs from these correlational and aggregate studies because we provide a thick description of the actual process involved in setting up a particular charter school, specifically a charter school attempting to institute a college-going culture of learning in a low-income neighborhood. We also highlight the dilemmas, institutional constraints, and political tensions, as well as the strategies and maneuvers invited by the process.

\section{The creation of a setting: Gompers Charter Middle School}

Despite the fact that research on the educational value of charter schools was mixed, parents, community organizers, and educators in the Gompers' neighborhood were so disgusted with the condition of their district-run neighborhood school that they turned to this radical alternative. In this section, we first present a brief history of the original Gompers Secondary School and the decision making of the key constituencies. Then, we describe the actions of the school district and the university, some of which enabled and some of which constrained the formation of this educational alternative.

\section{The past history of Gompers Secondary School}

The original Gompers Secondary School was an urban school housing grades 7 through 12 located in southeastern San Diego. It had operated for over 50 years in a community with a high crime rate and a lengthy history of gang-related violence. The school was redesigned several times in order to deal with educational and social challenges. It was identified as a racially isolated school in 1968. In response to court mandated desegregation orders issued in the Carlin vs. Board of Education San Diego Unified School District case in 1977, the school was designated as a math and science magnet school beginning in the 1978-1979 school year offering many unique and rigorous courses in computer programming and the sciences.

This experiment was abandoned in 2001 for three interconnected reasons. First, community members complained that the magnet school was segregated. Students bussed in from other parts of the city attended the magnet, while neighborhood students were for the most part confined to traditional classrooms on the other side of a chain-link fence. Second, when the school board ordered the magnet school to integrate neighborhood students into its classrooms in 1985, the curriculum was not 
modified to address their academic needs. Third, the school did not make the transition from mainframe computing to personal computer technology. Faced with these complications, many math and science teachers left the magnet school for more suburban assignments. The quality of instruction in math and science courses disintegrated. This experiment was terminated in the 2000-2001 school year (San Diego Unified School District 2008).

The school continued to follow the grades 7 through 12 configuration until it was divided into a middle school with grades 6 through 8 and a high school with grades 9 through 12 in 2004-2005. A newly constructed high school, to be known as Lincoln High School, was expected to open in 2006 at which time there were plans to close the original high school. Unable to meet its performance targets outlined by NCLB for 6 consecutive years, the middle school was required to restructure.

Deciding to convert Gompers to a charter school

A working group of parents, teachers, administrators, and community leaders (notably from the San Diego Chicano Federation, the United Front, the San Diego Organizing Project, and the San Diego Urban League) considered the following five options for restructuring Gompers Middle School provided by NCLB: contract with an effective external organization to run the school; reopen the school as a charter school; replace all or most of the school staff who were employed when the school did not attain annual yearly progress goals; turn operation of the school over to the state; and other major restructuring of the school's governance that would engender fundamental reform (NCLB 2001).

Michelle Evans, active parent, and Dora Mahar, school librarian, explained why they felt drastic change was needed:

Michelle Evans: So many people want to see change at Gompers. Not just parents. Not just teachers, but the administrators, the community. They all want to change. And this [restructuring the school] was our opportunity to invest in our kids' future. (Evans 2005)

Dora Mahar: These parents want more. The parents don't just want their children to work at menial jobs, working in hotels, cleaning bathrooms. That's not what they want. They want their children to go to college, go to medical school, law school, engineering school, to become teachers. That's their dream. That's the dream my parents had for me. We were immigrants too. (Mahar 2005)

Options quickly became limited. The State of California had declined to "take over" failing schools. Charter management organizations, such as Edison, ASPIRE, and Green Dot did not submit bids to manage any of the San Diego schools considering the charter option. In the absence of alternatives, the workgroup decided to consider charter status. Gompers' Middle School principal, Riveroll, convened meetings on Tuesdays and Thursday evenings starting in September 2004. These meetings were attended by many of the school's educators and a wide spectrum of parents. Mahar (2005) and Evans (2005) explain why parents preferred the charter option: 
Dora Mahar: There are a lot of good things about going charter. You get to select the teachers.

Michelle Evans: It's about local control. If we can control the teachers, the parents hold the teachers accountable, and the teachers hold the parents accountable.

It was at this point that UCSD was invited into the conversation. Because of the success of the Preuss School at UCSD in educating students from the Gompers' neighborhood, both Superintendent Alan Bersin and community leader John Johnson, who was leading a parallel Lincoln-Gompers' task force, asked Professors Cecil Lytle and Hugh Mehan to consider whether UCSD could "take over" Gompers and form a UCSD-sponsored charter school similar to the on-campus Preuss School. Citing the reticence of the new UCSD administration to manage another charter school, Lytle and Mehan agreed to participate in the formation of an independent charter school, but not a UCSD-sponsored charter school.

Through their affiliation with CREATE, Lytle and Mehan pledged material resources including UCSD students to serve as tutors, expertise in teacher professional development, research and evaluation, and parent education to the independent charter school. Perhaps more important than these material resources was the intellectual capital the university provided. CREATE offered a theory of action and model as a college prep school for the new Gompers. This idea resonated with Gompers' parents because more than 70 of them had one child at Preuss and another child in neighborhood schools at the time of the charter petition. Because the Gompers' parents knew first-hand that their students could be academically successful in a rigorous academic environment, they were motivated to support the idea of reforming Gompers into a college prep charter school as evidenced in the following comment:

Michelle Evans: We went door to door. We went in teams of two and three. And we walked this neighborhood.... We asked our teachers that were on the working group: Can you come and walk with us and meet your students? And they did. And that gave the charter validity because the teachers walked at night. They got off at 2:00 and they stayed until 5:00, 6:00. (Evans 2005)

These parents spoke with conviction based on their personal experience to the Gompers' work group at Tuesday and Thursday meetings, and later, to individual board members, the superintendent, the press, and at school board meetings.

\section{Enabling and constraining actions by San Diego city schools during the conversion process}

The actions of Superintendent Bersin of the San Diego City Schools (SDCS) and the SDCS board both facilitated and constrained supporters' efforts to convert its failing school to charter status in the 2004-2005 academic year. These enabling and constraining actions occurred during the conversion process and, in fact, continued after the school became a charter school. 
The mixed blessing of superintendent Bersin's blessing

From 1998 through 2005, SDCS engaged in a dramatic, daring, and possibly unprecedented reform. As prominent displays throughout the district asserted, "The mission of the San Diego City Schools is to improve student achievement by supporting teaching and learning in the classroom." To reach that commendable goal, the district under its newly appointed superintendent, Bersin, implemented a content-driven, centralized, comprehensive, and fast-paced reform (Hubbard et al. 2006; Mehan et al. 2005).

The reform was content-driven in that the development of literacy skills was at the forefront. Gains in student achievement were viewed as intimately linked to concerted efforts to improve instructional practice through sustained and focused professional development for teachers and educational leaders ranging from the principal to the superintendent. All educators were to be similarly focused on the teaching and learning of literacy. The reform was centralized in that major instructional and operational decisions emanated from the district leadership while instructional leaders, site content administrators, staff developers, and resource teachers provided guidance and direction to teachers. The reform was comprehensive in that all schools in the district were expected to implement all dimensions of the reform. Owing in part to leaders' characterization of the reform as a moral imperative and in part to the unique political pressures exerted on the district, the reform was fast-paced in that its major elements were introduced from the first days that the new district leadership took office. Instead of a preparation period, followed by a pilot phase, followed by full implementation, the district leaders chose to have their educators "learn to fly the plane while flying it."

Considerable impetus for a new approach to education within the district came from the San Diego business community. During the tenure of the previous superintendent, local business leaders had become increasingly critical about the poor preparation of high school graduates who were joining their firms. They argued that drastic changes in the public school system were needed to maintain the economic well-being of the San Diego region. The business community played a strong role in the selection of Bersin as superintendent and in the election of school board members who would support his reforms. Bersin, a well-known and widely respected attorney, was an appealing choice. He had a solid reputation and state and national connections. He had been a Rhodes Scholar at the same time as former President Bill Clinton. At the time of his appointment, he was the US attorney for the Southern California region and an advisor to California governor, Gray Davis.

Because Bersin had started his superintendancy committed to a comprehensive, centralized, content-driven approach to school reform, he initially opposed charter proposals such as the Preuss School that did not conform to the "Blueprint for Student Success" that guided the reform. He finally relented. The Preuss School and other charters were approved by the SDCS Board by 1998. By the end of his term in office, Bersin had become convinced that variation in school design and curricular implementation was acceptable and even desirable (Hubbard et al. 2006). Consistent with his new-found commitment to variation, he avidly supported the conversion of Gompers Middle School. 
Bersin's support of schools seeking charter status was a mixed blessing, however. The school board governing the SDCS changed composition in November of 2004. Previously, a 3-2 majority supported Superintendent Bersin's reform policies. After the November 2004 election, a 3-2 majority opposed his policies. This political shift led to the removal of Bersin as superintendent and affected the formation of GCMS. The newly elected board opposed, reflexively it seemed, any policy that Bersin supported. Therefore, Bersin's endorsement did not help Gompers win approval from the board for the conversion to charter status.

Despite his crippled political position, Superintendent Bersin was able to orchestrate support for schools seeking charter status. He instructed Brian Bennett, director of the district's Office of School Choice, and a practicing lawyer, to assist Gompers and the other schools traverse the often murky district policies and the state and federal laws covering governance, finance, and teachers' rights. Bennett boldly confronted the school board and the teacher's union on matters relating to teachers' status within the district, their benefits, and rights to return to the district. He met often with the Gompers' work group offering moral support and informal advice on writing the charter proposal and problems that seemed to emerge weekly. Without doubt, his moral support and legal advice facilitated the development and approval of the Gompers' charter, but it may have also contributed to the end of his career with the district. Bennett was terminated by Carl Cohn, who became superintendent after Bersin's departure.

Other organizations assisted the formation of GCMS often encouraged by Superintendent Bersin. The California Charter Schools Association (CCSA) provided start-up funds to Gompers and other schools to facilitate their conversions. CCSA staff members, notably Julie Umansky, provided advice on preparing charter documents for board approval and strategies for navigating the political landscape. Encouraged by Susan Wolking, the Girard Foundation provided funding for the first GCMS “culture camp" (described below) and training for board members on charter law and financing. The Girard Foundation also introduced GCMS to other foundations, which in turn, provided much needed financial support in subsequent years.

Board actions: Changing the rules of the game

While the Gompers community was in the process of establishing GCMS, the school board redefined the charter process, removed the popular and charismatic school principal who had been leading the conversion process, and delayed the approval of the charter. The previous school board had defined Gompers and two other schools as conversion charter schools which required charter petitioners to gather the signatures of $50 \%$ of the parents who were considering enrolling their children in the newly constituted schools. A coalition of black and Latino parents along with some Gompers Middle School teachers canvassed their neighborhood on behalf of the charter petition securing 700 out of 960 signatures from parents who were eligible to send their children to Gompers.

On January 7, 2005, the newly elected school board overturned the previous board's decision and defined Gompers Middle School a conversion charter, not a 
start-up charter. This new interpretation of state and federal law imposed a new demand on the petitioners to secure $50 \%$ of the permanent or unionized teachers' signatures within 2 weeks. This new demand placed teachers at the schools seeking charter status in a difficult situation. Voting in favor of the charter conversion would not guarantee their jobs because the charter leaders planned to interview all teachers for jobs regardless of previous employment at the school.

In a stunning display of professionalism and commitment to the idea of developing a new culture of learning, Sharletta Richardson, having been associated with the school for over 25 years, became a representative to the San Diego Education Association, the teacher's union. She was the first to sign the charter petition and encouraged her colleagues to do the same. She stated at the decisive school board meeting:

For 29 years I have commuted from Mira Mesa to teach at Gompers . . . when it was one of the leading academic schools in the district. In those past years, I have seen neighborhood students graduated from Gompers and go on to become teachers, lawyers, doctors, and engineers. I know our neighborhood students can achieve like that again. But because our demographics are different, and because we have very special needs, we need to do things differently. And Mr. DeBeck, that is why my name was the first on the list to support the Gompers Middle School charter. (Richardson 2005)

Representatives from the SDEA headquarters met with teachers and provided arguments against the conversion of Gompers to charter status, including the false claim that teachers would lose health and retirement benefits and the right to return to the district. After the dust settled, charter petitioners successfully obtained the approval of more than $50 \%$ of its teachers for its charter petition (Gao 2005a).

\section{Decapitating the movement's leadership}

The district's opposition to the conversion of Gompers Middle School to charter status did not end with its demand that petitioners obtain both teachers' and parents' signatures. In what looked like an attempt to destroy the growing momentum of the Gompers' work group, school board members decided on February 8, 2005 in a closed session to direct Superintendent Bersin to "transfer" Principal Vincent Riveroll from Gompers Middle School to the central office of the San Diego Unified as a "mentor principal" (Gao 2005a). From the time he was appointed as principal of Gompers Middle School in fall 2004, Riveroll instituted a number of dramatic changes to the school's structure and culture and supported the conversion of Gompers to a charter school. For many, the decision by the school board to remove the charismatic leader of the conversion movement embodied their general opposition toward charter schools demonstrating an "antipathy shared by a teacher's union that is adamantly opposed to the charter schools' exemption from union rules on teacher assignments and pay" (Sutton 2005).

After hearing the school board's decision to remove Riveroll, Gompers' supporters first erupted in angry protest, but soon continued defiantly with their 
charter school efforts. On February 14, 2005, community members met at the Chollas View Methodist Church across from the school where they deplored the unwarranted removal of Riveroll and pledged to continue their efforts on behalf of the charter. This attempt to decapitate the leadership failed. In fact, it seemed to energize efforts to convert Gompers Middle School to a charter school. Supporters organized letter writing and e-mail campaigns aimed at convincing the board to approve the charter.

\section{Understanding SDCS reticence}

Examined from the point of view of supporters of the conversion of Gompers Middle School to a charter school, the actions of the SDCS school board is inexplicable, even inexcusable. Examining these actions from the point of view of a school district or a teachers' union, however, reveals understandable reasons. Charter schools can be perceived as a threat to conventional public schools and their teachers' unions. Charter schools receive funding from the state for the students who enroll in them meaning a loss in funds and students from the district's inventory. Charter schools are not required to unionize which diminishes union membership and the hard-earned power to bargain on behalf of teachers.

Soon after they were advised by the SDCS district that they needed to restructure, the four schools considering charter status sought a waiver from the SDEA's contract with the district to allow the school to offer contracts directly to teachers without activating the seniority-based personnel policy centered at the district office. SDEA did not grant the waiver of the teacher hiring process citing procedural violations (Williams and Toch 2006). By the time Gompers and three other schools petitioned the board for charter status, 35 charter schools were already established in the district with 13,000 enrolled students, comprising almost $10 \%$ of the district's students and accounting for a loss of $\$ 70$ million in state funding ("A Test for Schools" 2008). Most of these charter schools were established in low-income neighborhoods with 30 of 35 located South of 8 .

Board members often expressed their concern about the increasing number of charter schools in the district-especially those South of 8 . They appealed to Gompers' parents to restructure their school under the guidance of the district. However, parents and teachers dismissed the idea of tinkering with educational programs or grade configurations. Repelled by a history of teacher vacancies and chaotic conditions, the work group was convinced that reopening Gompers as a charter was the only viable option.

\section{Questioning UCSD involvement}

UCSD's involvement was, in many ways, at the heart of the charter school debate. Whereas many Gompers' neighborhood parents supported UCSD's involvement and welcomed the resources the partnership promised, other actors including members of the UCSD administration, some community members, and an ambivalent school board were concerned about the extent of UCSD's involvement. 
Some members of the UCSD administration were particularly reticent about the campus's involvement in the charter school effort at Gompers. They expressed concern about the extent of UCSD's financial commitment and whether the effort was consistent with the university's mission.

School board members also worried that not enough faculty and staff members at the university endorsed UCSD's involvement with the same enthusiasm as Lytle and Mehan. UCSD, through CREATE, promised to bring material and intellectual resources to the school site with many being derived from successful developments at the Preuss School. Intellectual resources included advice on restructuring and reculturing the school to enable rigorous, college prep instruction for all students (Alvarez and Mehan 2005). Material resources encompassed UCSD students serving as tutors; a bus depositing tutors at GCMS and enabling parents to visit UCSD; professional development for the school staff; researchers compiling and analyzing information on students' performance and the school's development; interns providing teaching in math, science, and English/ESL; education opportunities informing parents about higher educational options and funding for their students; and faculty serving on the board of directors.

Members of the San Diego Unified School District Board of Trustees met with high-ranking members of the UCSD administration and Professors Lytle and Mehan in February 2005 to discuss UCSD's involvement in the Gompers' charter. UCSD administrators made it clear to those present at the meeting that UCSD had made no financial commitment to the effort. However, board members surprised those assembled by introducing an alternative restructuring plan. This plan emphasized "an autonomy in curriculum design and instruction, as well as flexibility in hiring teachers and extending the school day and school year, [where] the issue of hiring and increasing instructional time would have to be negotiated with the teachers union" (Gao 2005b, p. A1). Although board members alleged that this plan had been vetted with the university and the teachers' union, university officials made it clear to board members that they were unaware of this proposal (Gao 2005b). Thus, the alternative plan was flawed in that its authors had secured neither the union's nor the university's support. In a subsequent letter to the school board, the UCSD administration made it clear that the university was committed only to the plan devised by the GCMS planning group and that it was not planning to assume any direct financial management or administrative role in a Gompers' charter school (Fox 2005).

\section{Board approval}

The campaign to convert Gompers to a charter school in partnership with UCSD and community groups culminated on March 1, 2005 at a meeting of the SDUSD school board. Community leaders, Gompers' parents, and UCSD faculty urged the board to "give [their] children a way out of the trap of poverty, crime and despair.... [to] give them a chance for a decent education" (Sutton 2005, para. 4). Cecil Steppe, president of the Urban League of the San Diego County and parent of three graduates of Gompers, stated that the board should "stay within the law" by 
granting a charter to the organizers who obtained more than $70 \%$ of parental signatures, collected over $50 \%$ of the teachers' signatures additionally requested by the board, and who had Gompers' parents and educators who "have come back to you at least on two occasions and fulfilled every requirement that you laid on their plate." He further noted, "It seems to me with all of the struggles over the past, that it makes absolutely no sense in my mind for you to say no to an opportunity to bring a whole new way of doing business to a school that has been on the failure list for far too long" (Steppe 2005).

The charter proposal was not approved quietly. In public commentary at the meeting, one Gompers' teacher claimed that she had signed the charter petition without "the opportunity to look at it hard enough or deeply enough to give feedback or ask questions about it" because of "all the chaos...that was going on at Gompers." She wanted to withdraw her name from the petition. Trustee John DeBeck (2005) addressed this teacher's concern in his statement before voting:

We go back to the signature thing... I've only heard one person who came and said that they weren't sure about their signature. So, that's not going to cut it for me.... You have a community support that's strong, and [you met] the charter regulations said that we provided. I find it very difficult for me to vote against this charter with this situation.

Shirley Weber, professor and chair of the Department of Africana Studies at San Diego State University and a member of the San Diego school board from 19881996, expressed reservation about the four charter proposals before the board. She had seen "this board approve and reapprove charters that have failed year after year after year, without the guts to cut them off" further stating that "most of the conversion charters [South of 8] have not been successful, so that's a tremendous challenge to take one and make it successful." While saying that she believed Lytle's commitment "is true and honest" and the charter is not necessarily a bad concept, she pointed out that the charter document did not include parents on the governance team. She further wondered about the consequences for students whose parents failed to meet the requirements laid out in the charter: "When you say a parent must have 15 hours of volunteer, volunteerism, what happens if they don't? When you say they must come to open house, what happens if they don't?" (Weber 2005). These arguments were reiterated from the podium by Trustee Sheila Jackson even though she ultimately voted to grant the charter to Gompers.

Hence, after months of debate and a number of detours, the school board with a unanimous vote of 5 to 0 approved the petition to enable Gompers Middle School and three other schools (Memorial Academy, Keiller Middle School, and KingChavez elementary school) to restructure as 5-year charters. The GCMS charter called for enrolling students in grades 6, 7, and 8. As soon as the trustees finished their voting, the auditorium erupted in raucous applause. With charter status finally reached, Gompers was free to "move from a culture of survival to a culture of learning" (Riveroll as cited in Gao 2005c, p. A1). 


\section{Planning for and opening GCMS}

Time for celebration was short lived, however. The leadership team had only 6 months to take all the actions needed to start a school including sprucing up the campus; interviewing and hiring a principal, teachers, and support staff; designing a college-going culture for a neighborhood where this did not previously exist; obtaining books and other educational materials; securing funding; establishing the governing board; and most importantly, designing instruction that would be challenging and exciting for students.

The lack of quality teachers at the "old" Gompers had mobilized parents to change the school. GCMS leaders, like their counterparts at Preuss, gained control over personnel issues when they became a charter school. Becoming a charter enabled them to hire, promote, retain, and dismiss teachers at the school site exempting them from district personnel policies that awarded teaching positions on the basis of seniority. GCMS leaders believed scrapping the district's teacher-hiring option enabled the school to attract teachers who wanted to be at the school, who were committed to the education of GCMS students, and who were willing to contribute the extra time and energy it takes to improve the learning of underperforming students.

Forming the board of directors and hiring the director

Charter schools are often governed by boards of directors. Discussions about the configuration of the GCMS board and deciding its membership started immediately following the approval of the charter petition by the SDCS Board. The UCSD members of the planning team were asked to prepare a slate of board members composed of parents, teachers, community members, and UCSD faculty and staff. However, there was contention surrounding who should fill various positions, especially those for community representatives. Some members of the work group lobbied for community members representing local community groups while the ad hoc committee advocated for representatives with greater state and national visibility.

During an intense planning committee meeting, the issue was settled in favor of selecting former State Senator Dede Alpert, San Diego Urban League President Cecil Steppe, and Parent Institute for Quality Education President David Valladolid each of whom were community representatives with state, regional, and national reputations. In addition to these three community representatives, the initial board was composed of three parents, three educators, and three UCSD representatives.

At its initial meeting on May 28, 2005 at UCSD after dispensing with the necessary financial and legal matters, the newly formed GCMS Board of Directors quickly and unanimously elected Steppe as board chair and appointed Riveroll as director of the school.

Hiring quality teachers

At the same time as the board of directors was being composed, the school leaders had to move quickly to secure the initial teaching staff. As previously reported, the 
SDCS School Board removed Riveroll as director of the "old" Gompers in February of 2005. His subsequent reassignment to the district office inhibited his ability to recruit and interview prospective teachers. Feeling it was unethical to conduct GCMS business during SDCS business hours, Riveroll and an ad hoc personnel committee composed of GCMS administrators, parents, and CREATE personnel conducted recruitment interviews at UCSD throughout the week and some Saturdays from March to July of 2005.

Even teachers who previously taught at Gompers had to apply for positions at GCMS. Only 8 teachers were retained from the previous faculty, 39 out of 47 teachers were new to the school, and 34 of them were new to the teaching profession. Faced with an almost completely new teaching staff but committed to instilling a common culture among that staff, the GCMS leadership instituted a new practice which they called "culture camp."

Forging a common college-going culture of learning

Culture camp was held in the weeks immediately preceding the opening of the school in fall of 2005. Its purpose was to develop a common language, common expectations, and common ways of teachers and support staff (including custodians and safety officers) to interact with students. GCMS educators predicted the following: If all adults on the school site held the same high expectations for students, enforced the same rules and regulations, and treated indiscretions in the same manner, then the predicted stability resulting in the school environment would contribute to students' academic development and teachers' professional growth.

Teachers are now expected to adopt similar ways of assigning and receiving homework; organizing their classrooms, the school day, and lessons; and treating absences, tardies, and students' movements between classes. For example, all classrooms have a special place, usually a rug, for students to gather informally for discussions; and all teachers are encouraged to hang posters depicting learning strategies and material learned around their rooms so that students can consult them during subsequent classroom lessons.

Educators at GCMS, like educators at Preuss, recognize that the most effective form of teacher professional development occurs at the job site and is embedded in the work (Darling-Hammond 1997). Therefore, GCMS teachers engage in professional development activities at the school site during the school day. Teachers meet in grade level or department teams to plan collaboratively, examine students' work, and engage in "lesson study" (Lewis 2002).

To further ensure a common culture of learning at GCMS, the school secured a pool of substitute teachers on permanent call for work. Identified as "teachers on staff," this substitute teacher pool received training in the instructional practices employed at GCMS so instructional quality would not be reduced precipitously when taking over classrooms. The availability of on-call substitute teachers for GCMS provided the school director with some flexibility to provide professional development and revitalization opportunities for his teaching staff. Recognizing that knowledgeable substitutes are available, the director can invite teachers to attend professional development opportunities off-site or take a break when stress levels are high. 
Motivational signs and symbols of a college-going school culture

Motivational signs and other symbols are intended to reinforce the school's purpose of establishing a college-going culture of learning. College pennants decorate classroom and hallway walls. Students enter the school through "the Gates of Wisdom," an opening in the chain link fence surrounding the school that is now adorned with a large, inviting sign that reads: "Through this gate walk the finest people in the world" with a banner underneath indicating GCMS as "a UCSD partnership school." The school motto, "REACH," stands for respect, effort, achievement, citizenship, and hard work and appears ubiquitously. Parents are expected to sign a contract that explains the details of the school policy concerning uniforms, student behavior on campus, attendance, and consequences for noncompliance. Students are expected to be able to recite the school mission when asked by school personnel or visitors.

The clothing people wear is another visible symbol of the nascent college-going culture at GCMS. The teaching staff wears professional dress and the students use school uniforms. Both forms of dress are intended to signal to the students and the community that serious business occurs at Gompers. Not surprisingly, school uniforms invited some resistance from students and some parents, with students sometimes experiencing reluctance to wear their uniforms in the neighborhood for fear of reprisal from local gang members. As a result, students can be observed changing from street clothes to school uniforms on their way to and from school. As they approach the school, students pull up their sagging trousers and tuck in their shirts reversing the process on the way home.

Students and staff often negotiate appropriate standards of dress on campus. If students appear on campus without a uniform or with an incomplete uniform, they are not sent home. To ensure that such students do not miss class time for a violation of a behavioral expectation, they are lent uniform parts for the day. In the first 2 years, one staff member was assigned duty at the school entrance with the responsibility of enforcing the dress code. As students passed through the Gates of Wisdom, they were admonished to tuck in their shirts and pull up their trousers.

Not unexpectedly, students explore the boundaries of school rules concerning uniforms as well as other matters. Girls often tell stories of rolling up the hems of their skirts to make them shorter outside the gaze of their teachers. In a similar fashion, male GCMS students push their trousers down as far as they can get away with. Although the need for an official uniform policeman has diminished as students have increasingly conformed to the school's expectation for appropriate dress, faculty and staff can still be observed often imploring students to straighten up. Jocular exchanges now accompany attempts by staff to rebuff students' resistance to uniform rules.

Opening the school

The GCMS staff planned a grand opening for the school on Tuesday, September 5, 2005. Remarks by Director Riveroll, Board Chair Steppe, Councilman Tony Young, and the student council president were scheduled to welcome students, parents, and 
invited guests to the new school. Board of directors, elected officials, and philanthropists who had donated to the school, such as the Girard Foundation and the Jacobs Family Foundation, were in attendance. Students were to be ushered through the Gates of Wisdom to their classrooms by their teachers.

On the Thursday before the opening of the school, the office of California Governor Arnold Swarzenegger informed the planning group that the governor and the state secretary of education, Alan Bersin, wanted to celebrate the opening of the school. Because this was the only school he would visit on the traditional first day of school, the governor's request was interpreted as a high complement. However, this last minute announcement necessitated the GCMS faculty and board of directors to hurriedly make security and publicity plans and adjust the carefully planned opening day ceremonies. Ensuring that the plans to introduce the new academic orientation of the school to parents and students would not be swamped by the presence of a celebrity and addressing the nurses and teachers who were expected to picket the governor's presence became the work over the weekend between the governor's call and the school's opening.

The governor appeared after the morning opening ceremony which reinforced the well-planned event. The lunchtime press conference conducted by the governor and secretary of education was covered by the local press and television stations. Subsequent reports in the media gave positive publicity to the newly constituted school.

\section{Summary}

After months spent reviewing the various options provided by NCLB, the Gompers' work group, concluded that the school should be reconstituted as an independent charter school. Zealous parents, supported by dedicated teachers, secured signatures endorsing the charter petition from more than $70 \%$ of the parents whose students lived in Gompers' catchment area and 58\% of the school's teachers. On March 1, 2005, the San Diego Unified School District's Board of Education voted unanimously to grant the group its charter petition to form the Gompers Charter Middle School in partnership with UCSD and the GCMS community.

The GCMS academic plan crafted after months of weekly work group meetings called for making the school safe and inviting and instilling a common set of beliefs and values among youngsters and adults about appropriate behavior and learning, implementing a rigorous curriculum reinforced by academic and social supports, and engaging families and the community in the daily life of the school. It takes time to instill these conditions which are critical for increasing the possibility of equitable access to college and career for low-income students of color.

Constraints internal to the school made it difficult for GCMS to put these critical conditions in place for more than 800 students in the 6 months between the approval of the charter to the opening of the school. Challenges included hiring an entire teaching and support staff, refurbishing facilities, designing a college-going culture, coaching teachers in the adoption of the school's academic plan, and making learning rigorous and exciting for students. 
Circumstances external to the school also constrained the conversion. The school board supporting the superintendent was replaced by a board hostile to him and his commitment to charter schools. This newly elected school board changed the rules governing the charter petition process. Charter school advocates had to scurry to obtain teachers' approval even after they had secured parents' approval. The San Diego Education Association challenged agreements between the district and the union that allowed district teachers to be on loan to charters, thereby causing anxiety and uncertainty among affected teachers. The California Charter Schools Association, SDCS staff led by Brian Bennett of the School Choice Office, and local philanthropic organizations, notably the Girard Foundation, helped charter advocates navigate around these obstacles. UCSD's partnership with GCMS, while helpful, produced its own troubles. On the one hand, faculty associated with CREATE were able to assist GCMS traverse the uncertainties of the political process and promise considerable resources for the school. On the other hand, the uneven record of UCSD in communities of color and the less-than-enthusiastic commitment of the central administration toward community engagement required CREATE to proceed cautiously and negotiate trust repeatedly.

\section{Conclusions and implications for future research}

Charter schools reside in the middle of an intense public debate about the quality of public education in general and the limited access to quality schooling among underserved populations with particular provocation by A Nation at Risk and NCLB. Advocates tout charter schools as stimulants to innovation claiming that they provide more choice to parents and offer different models of organization, curriculum, and instruction while opponents dress them down as the first steps toward the privatization of public education.

This story does not settle the disputes among proponents and opponents of charter schools concerning the relative strengths of traditional public schools and public charter schools such as whether charter schools foster competition in public schools or increase racial segregation. This story does, however, help fill a gap in the literature on charter schools. By reporting "the creation of a setting" (Sarason 1972, 1997) at GCMS rather than discussing charter schools in the aggregate, this story provides insight into the often contentious processes associated with moving from initial impulse to routinized practice. Hopefully, this story about the transformation of "passion into practice" (Deal and Hentschke 2004, p. x) will be useful to scholars conducting research on charter schools and community members interested in establishing them.

While this study takes up Sarason's $(1972,1997)$ injunction to study the creation of a reform effort, in closing we would also like to engage in a conversation with another dimension of Sarason's work. Sarason (1982) famously concluded that educators' well-ingrained habits and an organization's standard operating procedures could derail even the best-intended and well-organized reform efforts. Sarason's observations are trenchant because they focused the researcher's gaze beyond the technical dimension of school reform, that is, beyond the idea that 
improving teacher training, reducing class size, or adding more computers would induce improvements.

Sarason is certainly correct in asserting that studies of school reform need to take aspects of organizational culture as well as attempts to make technical changes into account, however we think he underestimates the importance of the political dimensions of reform. The complexities surrounding the reform efforts reported here suggest that researchers need to devote as much attention to power politics and conflicts between stakeholders as they do to organizational culture and technical suggestions for change.

This injunction applies as well to educators who are considering opening new schools whether they are charter schools or private schools in the US or abroad. No matter how carefully they have drawn their plans for the academic program of a new school, educators must take teachers' values and beliefs about students' capabilities and their often implicit theories of learning and the organization of instruction into account. Equally important to these subtle cultural dynamics are community politics and power politics. As we learn from the messy details associated with the constitution of Gompers as a new charter school, unless the major constituencies are aligned, the prospects for significant reform are diminished. Faculty members from UC Berkeley, UC Davis, Arizona State University, the University of Arizona, the University of Chicago, and the University of Pennsylvania accompanied by educators from their local school districts are applying this lesson. Each has developed a model school in a low-income neighborhood close to their campuses. In a manner analogous to CREATE's involvement with Preuss and Gompers, university faculty assist with the development of governance, finances, curriculum, instruction, and assessment of their model school's progress. Each "university supported school" is to serve as a model for educational rejuvenation in the local community (Quartz 2007).

\section{Epilogue}

While this paper reports only on the origin of Gompers, some time has passed since then providing indications of how the school is doing. When the school opened in fall 2005, more than 900 students enrolled. Unprepared for this onslaught, the school scrambled to find a sufficient number of teachers to educate the students. Since then, student enrollment in grades 6 through 8 has settled at 780, a student population that the school's administration feels is more consistent with the school's academic mission. GCMS has displayed steady academic progress as measured by NCLB's accountability guidelines. The Academic Performance Index (API) of the former Gompers in its closing year was 540 on a scale of 100 to 900 . In 2009, the API score was 621 yielding a gain of 81 points.

The most significant development is the expansion of Gompers from a grade 6-8 middle school to a 6-12 high school. Renamed to Gompers Preparatory Academy (GPA) to indicate its college preparatory orientation, Gompers has added one grade level at a time starting with a 9th grade in 2008. GPA's director, Riveroll, 
anticipates an enrollment of 1,000 students approximating 140 students at each grade level by the time it graduates its first senior class.

The Gates of Wisdom at Gompers Charter Middle School now stand open. As significant as that event is, the work of building a world-class school for the education of students of color is not complete. Indeed, it has just started. A high proportion of students enroll at Gompers speaking a language other than English. More than $50 \%$ enroll with reading and math skills well below grade level expectations. Teachers leave the school due to the extensive demands on their time and energy. These are among the most pressing challenges confronting the Gompers' educators. With that said, the current upper management of the SDUSD has adopted a more receptive attitude toward Gompers lessening the political tension between the school and the district. The progress of GCMS will be described in future reports.

Acknowledgments We appreciate the support of the Spencer Foundation in the writing of this paper. The foundation does not necessarily endorse the analysis in the paper. Insightful comments offered by Allison Kenda, Amanda Datnow, and Cecil Lytle were especially helpful.

Open Access This article is distributed under the terms of the Creative Commons Attribution Noncommercial License which permits any noncommercial use, distribution, and reproduction in any medium, provided the original author(s) and source are credited.

\section{References}

Alvarez, D., \& Mehan, H. (2005). Whole school detracking: A strategy for equity and excellence. Theory Into Practice, 45(1), 82-89.

Betts, J., \& Hill, P. T. (2006). Key issues in studying charter schools and achievement: A review and suggestions for national guidelines. Seattle, WA: University of Washington, Center on Reinventing Public Education.

Bulkley, K. E., \& Wohlstetter, P. (Eds.). (2004). Taking account of charter schools: What's happened and what's next?. New York: Teachers College Press.

Carnoy, M., Jacobsen, R., Mishel, L., \& Rothstein, R. (2005). The charter school dust-up: Examining the evidence on enrollment and achievement. New York: Teachers College Press.

Center for Educational Reform. (2004, August 25). Charter school evaluation reported by the New York Times fails to meet professional standards (Paid Advertisement). New York Times. Retrieved from http://www.nytimes.com.

Chubb, J. E., \& Moe, T. M. (1990). Politics, markets and America's schools. Washington, DC: The Brookings Institute.

Cicourel, A. V. (1964). Method and measurement in sociology. New York: The Free Press.

Darling-Hammond, L. (1997). The right to learn: A blueprint for creating schools that work. San Francisco: Jossey-Bass.

Deal, T. E., \& Hentschke, G. C. (2004). Adventures of charter school creators: Leading from the ground up. Lanham, MD: Scarecrow Education.

DeBeck, J. (2005, March 1). Remarks before the Board of Trustees. San Diego, CA: San Diego Unified School District.

DeBray-Pelot, E. H., Lubienski, C. A., \& Scott, J. T. (2007). The institutional landscape of interest group politics and school choice. Peabody Journal of Education, 82(2/3), 204-230.

Evans, M. (2005, March 1). Remarks before the Board of Trustees. San Diego, CA: San Diego Unified School District.

Fox, M. A. (2005). Letter to the Board of Trustees, San Diego Unified School District. La Jolla, CA: UCSD. 
Fuller, B. (Ed.). (2000). Inside charter schools: The paradox of racial decentralization. Cambridge, MA: Harvard University Press.

Gao, H. (2005a, February 10). Popular Gompers principal loses post: Reassigned leader has cracked charter efforts. San Diego Union Tribune, p. A1.

Gao, H. (2005b, February 28). Schools await charter decision: San Diego Board is expected to vote on achievement plans. San Diego Union Tribune, p. A1.

Gao, H. (2005c, March 2). Four schools win charter status: Low achievers hope to turn things around. San Diego Union Tribune, p. A1.

Hart, G., \& Burr, S. (1996). The story of California's charter school legislation. Phi Delta Kappan, 78(1), $37-40$.

Hassel, B. C., \& Terrell, M. G. (2006). Charter school achievement: What we know. Washington, DC: National Alliance for Public Charter Schools.

Hubbard, L., \& Kulkarni, R. (2009). Charter schools: Learning from the past, planning for the future. Journal of Educational Change, 10(2/3), 173-189.

Hubbard, L., Mehan, H., \& Stein, M. K. (2006). Reform as learning: School reform, organizational culture, and community politics in San Diego. New York: Routledge.

Kenda, A. (2008, January). The restructuring and reculturing of a neighborhood school. Paper presented at the meeting of the California Charter School Association and the Keiller Leadership Academy, San Diego, CA.

Lewis, C. C. (2002). Lesson study: A handbook of teacher-led instructional change. Philadelphia: Research for Better Schools.

Lubienski, C. (2004). Charter school innovation in theory and practice: Autonomy, R\&D, and curricular conformity. In K. E. Bulkley \& P. Wohlstetter (Eds.), Taking account of charter schools: What's happened and what's next? (pp. 72-90). New York: Teachers College Press.

Mahar, D. (2005). Interview by S. Bradley [Television]. In S. Bradley (Producer), UCSD impact: Charter schools. San Diego, CA: UCSD TV.

McClure, L., Strick, B., Jacob-Almeida, R., \& Reicher, C. (2005). The Preuss School at UCSD: School characteristics and students' achievement. Retrieved from University of California, San Diego, Center for Research on Educational Equity, Assessment, and Teaching Excellence website: http://create.ucsd.edu/Research_Evaluation/PreussReportDecember2005.pdf.

Mehan, H., Hubbard, L., \& Stein, M. K. (2005). When reforms travel: The sequel. Journal of Educational Change, 6(4), 329-362.

Meier, D. (1995). The power of their ideas: Lessons for America from a small school in Harlem. Boston: Beacon Press.

Merseth, K. K., Cooper, K., Roberts, J., Tieken, M. C., Valant, J., \& Wayne, C. (2009). Inside urban charter schools: Promising practices and strategies in five high-performing schools. Cambridge, MA: Harvard Education Press.

Miron, G., \& Nelson, C. (2002). What's public about charter schools?: Lessons learned about choice and accountability. Thousand Oaks, CA: Corwin Press.

Nehring, J. (2002). Upstart startup: Creating and sustaining a public charter school. New York: Teachers College Press.

No Child Left Behind Act of 2001, Pub. L. No. 107-110, § 115, Stat. 1425 (2001).

Quartz, K. H. (2007). University assisted schools: From laboratory schools to engaged scholarship (Policy Brief). Retrieved from University of California, San Diego, Center for Research on Educational Equity, Assessment, and Teaching Excellence website: http://create.ucsd.edu/ collaborations/UC-assisted\%20schools\%20Policy\%20Brief7-19-07.pdf.

Renzulli, L. A., \& Roscigno, V. J. (2007). Charter schools and the public good. Contexts, 6(1), 31-36.

Richardson, S. (2005, March 1). Remarks before the Board of Trustees. San Diego, CA: San Diego Unified School District.

Rofes, E. (2000). Teachers as communitarians: A charter school cooperative in Minnesota. In B. Fuller (Ed.), Inside charter schools: The paradox of racial decentralization (pp. 203-229). Cambridge, MA: Harvard University Press.

Saadati, M. (2005, March 1). Remarks before the Board of Trustees. San Diego, CA: San Diego Unified School District.

San Diego Unified School District. (2008, April). MAP Proposal. San Diego, CA: Millennial Tech Middle School.

Sarason, S. (1972). The creation of settings and the future of societies. San Francisco: Jossey-Bass. 
Sarason, S. (1982). The culture of the school and the problem of change (2nd ed.). Boston: Allyn and Bacon.

Sarason, S. (1997). Revising the 'Creation of settings'. Mind, Culture and Activity, 4(3), 175-182.

Schorr, J. (2002). Hard lessons: The promise of an inner city charter school. New York: Ballantine Books.

Scott, J. (2009). The politics of venture philanthropy in charter school policy and advocacy. Educational Policy, 23(1), 106-136.

Steppe, C. (2005, March 1). Remarks before the Board of Trustees. San Diego, CA: San Diego Unified School District.

Sutton, M. (2005, March 10). Note to school board: Take the next step—give Riveroll back to Gompers. Voice of San Diego. Retrieved from http://voiceofsandiego.org/.

A test for schools. (2008, March 3). Voice of San Diego. Retrieved from http://voiceofsandiego.org.

US Department of Education. (1997). A study of charter schools: First-year report. Washington, DC: Office of Educational Research and Improvement.

Vergari, S. (2002). The charter school landscape. Pittsburgh, PA: University of Pittsburgh Press.

Weber, S. (2005, March 1). Remarks before the Board of Trustees. San Diego, CA: San Diego Unified School District.

Wells, A. S., et al. (1998). Beyond the rhetoric of charter school reform: A study of ten California school districts. Retrieved from University of California, Los Angeles website: http://www.gseis.ucla.edu/ docs/charter.pdf.

Wells, A. S. (Ed.). (2002). Where charter school policy fails: The problems of accountability and equity. New York: Teachers College Press.

Wells, A. S., Holme, J. J., \& Vasudeva, A. (2000). Diversity and inequality: Montera Charter High School. In B. Fuller (Ed.), Inside charter schools: The paradox of racial decentralization (pp. 144176). Cambridge, MA: Harvard University Press.

Williams, J., \& Toch, T. (2006). Extreme makeover: Two failing San Diego schools get new start as charters. Washington, DC: Education Sector.

Ziebarth, T., Celio, M. B., Lake, R. J., \& Rainey, L. (2005). The charter schools landscape in 2005. In R. J. Lake \& P. T. Hill (Eds.), Hopes, fears, and reality: A balanced look at American charter schools in 2005. Seattle, WA: Center on Reinventing Public Education.

Zimmer, R., Gill, B., Booker, K., Lavertu, S., Sass, T. R., \& Witte, J. (2009). Charter schools in eight states: Effects on achievement, attainment, integration, and competition. Santa Monica, CA: RAND Corporation. 